\title{
P031: Room for improvement of clostridium difficile surveillance and reporting in denmark
}

\author{
M Chaine ${ }^{1,2^{*}}$, S Gubbels², E Tvenstrup Jensen ${ }^{1}$, M Voldstedlund $^{2}$, K Mølbak $^{2}$, B Kristensen ${ }^{1}$ \\ From 2nd International Conference on Prevention and Infection Control (ICPIC 2013) \\ Geneva, Switzerland. 25-28 June 2013
}

\section{Introduction}

National surveillance of Clostridium Difficile (CD) is currently performed in two ways in Denmark: by the Enteropathogen Registry (TBR) for all CD culture positive samples (reported from clinical microbiology laboratories), and since 2009 by a specific CD027 Registry with mandatory submission of $\mathrm{CD}$ strains for further characterization.

\section{Objectives}

In this study the two systems are evaluated with a focus on completeness.

\section{Methods}

From the TBR and the CD027 registry datasets were retrieved with data from January $1^{\text {st }} 2011$ to December $31^{\text {st }} 2012$ including information on date of sample and region of diagnostic microbiology department. For both, a patient was included only once during the observation period.

\section{Results}

A total of 5342 patients were reported with CD in the TBR registry and 1971 patients in the CD027 registry. For the whole country the TBR showed a stable linear trend of percentages over the observation period with a coefficient of correlation $\left(R^{2}\right)$ of 0.0072 , whereas the CD027 Registry showed a decreasing trend with $R^{2}=0.52$. Two regions accounted for a total of 1828 cases of CD027. Moreover, one of these regions recorded more cases in the CD027 registry than in the TBR in 19 of 24 months of the observation period.

\section{Conclusion}

The decrease in number of cases in the CD027 registry may show a decrease in completeness as it coincided

${ }^{1}$ Microbiology and Infection Control, Copenhagen, Denmark

Full list of author information is available at the end of the article with known changes in laboratory practices. The observation that more cases from one of the regions were recorded in the CD027 Registry than in the TBR suggests an underreporting in the TBR register for this region. This shows there is a need for a surveillance system with higher completeness, which records ribotypes. The newly established Danish national microbiology database (MiBa), which includes all test results from all diagnostic microbiology departments, may provide the basis for such a system.

\section{Disclosure of interest}

None declared.

\section{Author details}

'Microbiology and Infection Control, Copenhagen, Denmark. ${ }^{2}$ Infectious Disease Epidemiology, Statens Serum Institut, Copenhagen, Denmark.

Published: 20 June 2013

\section{doi:10.1186/2047-2994-2-S1-P31}

Cite this article as: Chaine et al:: P031: Room for improvement of clostridium difficile surveillance and reporting in denmark. Antimicrobial Resistance and Infection Control 2013 2(Suppl 1):P31.

Submit your next manuscript to BioMed Central and take full advantage of:

- Convenient online submission

- Thorough peer review

- No space constraints or color figure charges

- Immediate publication on acceptance

- Inclusion in PubMed, CAS, Scopus and Google Scholar

- Research which is freely available for redistribution

\section{() Biomed Central}

